\title{
HAIL RAIN AND ITS GEOGRAPHICAL REPERCUSSIONS IN THE COUNTRYSIDE OF SÃO PAULO (SP) STATE
}

https://doi.org/10.4215/rm2019.e18006

\author{
Maia, D. C. $a^{*}$ - Fontão, P. A. B. b - Souza, L. B. c \\ Christofoletti, A. L. H. d - Azevedo, T. S. De e
}

(a) Doutor em Geografia, Universidade Estadual Paulista (UNESP - Rio Claro)

ORCID: https://orcid.org/0000-0003-3286-9256. LATTES: http://lattes.cnpq.br/5639903221161332.

(b) Doutor em Geografia, Universidade Estadual Paulista (UNESP - Rio Claro)

ORCID: https://orcid.org/0000-0002-7293-2742. LATTES: http://lattes.cnpq.br/7615025096908509.

(c) Doutor em Geografia, Universidade Federal de Tocantins (UFT - Porto Nacional)

ORCID: https://orcid.org/0000-0001-7957-088X. LATTES: http://lattes.cnpq.br/8310303536103062.

(d) Doutor em Geociências e Meio Ambiente, Universidade Estadual Paulista (UNESP - Rio Claro)

ORCID: https://orcid.org/0000-0001-8961-5332. LATTES: http://lattes.cnpq.br/6145995445352330.

(e) Doutor em Geografia, Universidade Estadual Paulista (UNESP - Rio Claro)

ORCID: https://orcid.org/0000-0003-4802-0927. LATTES: http://lattes.cnpq.br/0445268569159693.

\section{Article history: \\ Received 22 May, 2017 Accepted 03 March, 2019} Published 15 March, 2019

\section{(*) CORRESPONDING AUTHOR}

Address: Departamento de Geografia - Instituto de Geociências e Ciências Exatas -Universidade Estadual Paulista, CEP: 13506-900, Rio Claro (SP), Brasil. Tel: (+55 19) 3526-9206.

E-mail: diegom@rc.unesp.br

\section{ABSTRACT}

This article aims to perform an analysis of episodic characteristics of the spatial repercussions of the hail storm that occurred in the autumn of 2016 , in the urban area of Rio Claro (SP). Through the radar images were examined the genesis, the evolution and the spatial temporal dissipation of the phenomenon. In this context, it was sought to highlight the atmospheric systems operating in the week of hail precipitation episode, occurred on the night of June 1th 2016. To analyze the socioeconomic impacts generated by hail rain, was used information provided by the Civil Defense. The use of statistical techniques, it was possible to verify the correlation between the occurrences recorded by Civil Defense, the social vulnerability aspect in the most affected areas and the type of cover used in the roofs of the dwellings.

Keywords: Hail; Geostatistical tools; Civil Defense; Social Vulnerability.

\section{RESUMO / RESUMEN}

\section{TEMPESTADE DE GRANIZO E SUAS REPERCUSSÕES GEOGRÁFICAS NO INTERIOR PAULISTA}

Este artigo tem como objetivo compreender os eventos extremos de chuva de granizo e as repercussões espaciais desse fenômeno na área urbana da cidade de Rio Claro (SP). Usando as imagens de radar, foram examinadas a gênese, a evolução e a dissipação espaço-temporal do fenômeno, e nesse contexto, buscou-se destacar os sistemas atmosféricos atuantes na noite de $1^{\circ}$ de junho de 2016 . Para analisar os impactos socioeconômicos gerados foram utilizadas informações das ocorrências registradas pela Defesa Civil. A utilização de técnicas geoestatísticas possibilitou verificar a correlação entre as ocorrências registradas pela Defesa Civil, a vulnerabilidade social nas áreas mais atingidas e o tipo de material construtivo utilizado nos telhados das moradias.

Palavras-chave: Granizo; Técnicas Geoestatísticas; Defesa Civil; Vulnerabilidade social.

\section{TORMENTA DE GRANIZO Y SUS REPERCUSIONES GEOGRÁFICAS EN EL INTERIOR DEL ESTADO DE SÃO PAULO}

Este artículo pretende realizar un análisis de carácter episódico del impacto espacial del la lluvia de granizo, que ocurrió en el otoño de 2016, el área urbana de Rio Claro (SP). Por medio de las imágenes de radar se examinaron la génesis, la evolución y la disipación espacial del fenómeno, y en este contexto, se resaltó los sistemas atmosféricos más actuantes en la semana de lo episodio de precipitación de granizo, que ocorrió en la noche del 1 de junio 2016. Para el análisis de los impactos socio-económicos causados por el granizo, se utiliza la información proporcionada por la Defensa Civil y los medios de comunicación impresos. Con el uso de técnicas estadísticas, fue posible verificar la correlación entre las ocurrencias registradas por la Defensa Civil, el aspecto de la vulnerabilidad social en las áreas más afectadas y el tipo de cobertura utilizada en los tejados de las viviendas.

Palabras-clave: Granizo; Técnicas Geoestadísticas; Defensa Civil; Vulnerabilidad social. 


\section{INTRODUCTION}

The impacts of hailstorms are becoming increasingly relevant because of their undeniable threat to human activities, since such incidents are sudden and inevitable. As they are storms inherent to atmospheric dynamism, this phenomenon usually has a higher frequency in the middle latitudes, specifically in North America, central Europe, boreal India (hail belts), southern China, southeast Australia and the southern region of South America (CUNHA, 2003).

In Brazil, hailstorms orchuva de pedra, as they are popularly known, are mainly concentrated in the states of Paraná, Santa Catarina and Rio Grande do Sul (MARTINS et al., 2017). However, there is still a great spatial variability of the incidents in the Brazilian territory and, although less frequent when compared to the southern Region of the country, in the State of São Paulo such episodes are associated to types of intense rainfall.

According to Conti (1981), the phenomenon of hail is recurrent in the State of São Paulo, specifically in mountainous areas and high plateaus, and there is a correlation between the incidence of hail and altitude. Among various examples, the author demonstrates, through episodic analysis, the impact of the hailstorm that occurred in the spring of 1975 in Atibaia (SP), which devastated much of the peach, grape and coffee plantations.

According to Gomes et al. (2010), these storms can occur in the territory of São Paulo throughout the year, and although there are some records of such episodes in winter, the highest frequency occurs in the spring-summer months. This meteorological configuration is due to the fact that the State of São Paulo is located in an area of climatic transition (MONTEIRO, 1969; 1973), subject to the performance of intra and extratropical atmospheric systems and, consequently, intense frontal activity throughout the year.

Classically, hail is characterized as a precipitation of grains of ice during a storm (BLAIR and FITE, 1964). This event is caused by the presence of cumulonimbus clouds, which can reach up to 15 kilometers in height. Among the conditions necessary for the formation of hail, is the occurrence of upward currents of air inside the cloud that are responsible for carrying the water droplets to be solidified at high altitude in the form of ice. When the hail dissolves, due to the warming carried out by the friction with the ascending air currents, the precipitation takes place in the form of rain (liquid). However, when the storms are more severe and the descending winds are more intense, the hail does not liquefy, reaching the surface of the ground.

The phenomenon is generally associated with mesoscale convective systems derived from tropical instabilities and lasting less than the total time of the rainfall (BARRY and CHORLEY, 2013). As its area of occurrence and the duration between the synoptic scale and the individual rain cells is intermediate, there is considerable difficulty in predicting, measuring and assessing their impacts.

The particular configuration of this atmospheric phenomenon makes studying them very difficult, since their occurrence is often restricted to reports by residents, local newspapers and databases from natural disaster monitoring bodies, such as the Integrated Disasters Information System (S2ID), which integrates several products of the National Secretariat for Civil Defense and Protection.

Research on hail and its repercussions has mostly been focused on the damage caused in rural areas, mainly affecting farming and livestock (CANTOS et al., 1998; CUNHA et al., 2001; KLANOVICZ, 2013). In this sense, articles that refer to the damage caused by hail in urban areas are rare, especially those related to the trajectory of the convective system. In addition to the impacts on the agricultural system, such severe weather events can also lead to great destruction in the urban environment, causing considerable damage to residential roofs and windows, felling trees and electrical cables, damaging vehicles, blocking manholes and, in extreme cases, even resulting in the deaths of people and animals hit by hailstones.

The present article aims to understand the spatial repercussions caused by hailstorms, correlated to social vulnerability and the damage caused in the urban area of Rio Claro - SP, resulting from the event of June 1, 2016.

\section{MATERIALS AND METHODS}


The municipality of Rio Claro (SP) is located in the central portion of the State of São Paulo, with an estimated population of 201,473 inhabitants in the year 2016, of which $97.5 \%$ live in the urban area (IBGE , 2017).

Rio Claro is located in the geomorphologic region of the São Paulo peripheral depression (ROSS and MOROZ, 1997), and thus does not have great topographic differences within the municipal boundaries, with altitudes around 600 meters. However, the area in question is relatively close to the region of the basaltic slopes (around $30 \mathrm{~km}$ ), located to the west - northwest of the municipality, whose altitudes can reach 1,200 meters.

For the episodic analysis of the phenomenon, data were collected from the meteorological station of Rio Claro, which belongs to the Center for Analysis and Environmental Planning (CEAPLA), located at the University of São Paulo (UNESP) Campus, in the urban area of the municipality. The variables collected were temperature, atmospheric pressure, radiation, wind and precipitation, at 10-minute intervals throughout the day.

The atmospheric dynamics analysis was carried out by the observation of the Brazilian Navy's synoptic charts and the meteorological satellite images of the Center for Weather Forecasting and Climate Studies (CPTEC / INPE).

Understanding the event requires an analysis of the variables that preceded and succeeded the episode. Taking this precept into consideration, the data analyzed covers the period from May 24 to July $2,2016$.

This procedure was carried out in order to verify the atmospheric dynamics of the hail storm, which is inherent to the climatic rhythm at the regional level (ZAVATTINI and BOIN, 2013; MONTEIRO, 2015). In addition, observations and analyses of the trajectory of the convective system that devastated the city of Rio Claro were carried out, using, at this stage, the images produced on June 1, 2016 by the meteorological radar of the Meteorological Research Institute of Bauru (IPMET), with a 15-minute time scale, associated to the altimetric map of the State of São Paulo, made available by the Brazilian Agricultural Research Corporation - EMBRAPA - (MIRANDA et al., 2017).

The displacement of the convective system, responsible for the hail storm, was georeferenced and superimposed on the altimetric map in the Geographic Information System - SIG, using the ArcGis application, version 10.2. From this procedure, a cartographic document was created that permitted the trajectory of the atmospheric system to be estimated.

To create the spatial analysis of the damage caused by the hailstorms, the occurrences recorded by the Municipal Civil Defense were used. The damage was organized into typologies and later georeferenced by the occurrence's address, by means of a digital map provided by the Municipal Government.

The information containing the UTM coordinates of each episode and its respective damage were exported to ArcGis 10.2 software in order to spatialize the critical damage areas. This was done using the kernel estimator of density, a non-parametric method that is widely used to verify the behavior of point patterns. Thus, a two-dimensional function was created on the occurrences of damage, proportional to the area of occurrence. In this way, the kernel function (Equation 1) is the sum of all the samples within a radius of influence that is estimated by the distance of each point (CARVALHO and CAMARA, 2004; FOTHERINGHAM et al . 2000).

$$
\lambda_{\tau}(u)=\sum_{h_{j} \leq \tau} \frac{3}{\pi \tau^{2}}\left(1-\frac{h_{i}^{2}}{t^{2}}\right)^{2}
$$

(1)

where:

$t$ is the radius of influence.

$\mathrm{h}$ is the distance between the center of the region of influence and the points observed.

Thus, the kernel density estimator is calculated from the location $\mu$ from $n$ events contained in a 
radius of size $t$ around $\mu$ and the distance $d$ between the position and the $i$-th sample (CARVALHO and CAMARA, 2004), according to equation 2 :

$$
\lambda_{\tau}(u)=\frac{1}{\tau^{2}} \sum_{i=1}^{n} K\left(\frac{d\left(u_{i}, u\right)}{\tau}\right), d\left(u_{i}, u\right) \leq \tau
$$

(2)

where:

$\mathrm{K}$ is the number of experimental pairs of observations,

$\mathrm{d}$ is the distance between the position and the $i$-th sample.

To determine the radius of influence, a variographic analysis was performed to estimate the spatial correlation of the studied variable, thus determining the zone of influence around the samples (YAMAMOTO and LAMDIM, 2013). The final result of this procedure was the compilation of four qualitative choropleth maps, which show the different densities of the types of damage (trees and cables, damaged windows and roofs), identifying the areas most affected by hailstorms in the city of Rio Claro SP.

Owing to the extent of the damage, given the large number of damaged roofs, and in order to detail the impacts, a spatial analysis of the critical areas was also performed, relating the occurrence of the damage to the social vulnerability of that space in the Paulista Social Vulnerability Index (IPVS).

This indicator, created by the State System of Data Analysis Foundation (SEADE), is an index that presents the different economic and social performance of the municipalities in São Paulo state. Based on income, schooling and the family life cycle, this variable is based on the spatial identification of the areas of vulnerability of the resident population, classifying the urban census sectors into six classes, which vary from very low or no vulnerability to very high vulnerability (SÃO PAULO, 2013).

The procedures adopted in this phase of the research consisted, first, in the adoption of a spatial plan, based on spatial information from the census tracts of the municipality of Rio Claro in the "shapefile" format of the Estatcart georeferenced information system, developed by the Brazilian Institute of Geography and Statistics - IBGE - (BRAZIL, 2010). This information base was exported to ArcGis 10.2, where a database was compiled with information on the occurrences of damage caused by hail on roofs, recorded by Civil Defense and the Paulista Index of Social Vulnerability (IPVS).

This analysis allowed a spatial correlation of the critical areas of the occurrence of this type of damage in the urban census sectors of Rio Claro to be established. From the procedures found in Fotheringham et al. (2000), the Multivariate Local Indicator of Spatial Association - LISA was used to determine which census tracts presented the most significant spatial associations of damaged roofs in relation to social vulnerability (Equation 3).

$$
\mathrm{I}_{\mathrm{kl}}^{\mathrm{i}}=\mathrm{Z}_{\mathrm{k}}^{\mathrm{i}} \sum_{\mathrm{j}} \mathrm{W}_{\mathrm{ij}} \mathrm{Z}_{\mathrm{l}}^{\mathrm{j}}
$$

(3)

where:

$\mathrm{I}=$ Local Moran Index;

$\mathrm{Z}=$ Standardized variables;

$\Sigma \mathrm{j}=$ Sum between each line $\mathrm{i}$ of the spatial matrix;

$\mathrm{W} \mathrm{ij}=$ elements of the first order standardized spatial proximity matrix $\mathrm{W}$.

In order to perform this procedure, first, the indicator I(I-Moran Local) was calculated on $\mathrm{R}$ software. The significance of this analysis was stipulated by the permutation of the randomness of the value of the adjacent areas until a pseudo distribution was obtained (p). These parameters were 
calculated from 999 random permutations of the values of $I$, resulting from the correlation of the events studied (Bivand, 1998; CRESSIE, 1993). The calculation of the value $-p$ was carried out as follows:

1- Calculation of the index $I(0)$ for the observed data on damaged roofs of all $n$ samples (the 262 census tracts of Rio Claro);

2- Calculation of the index I(1), randomly exchanging roof damage values against the social vulnerability of all 262 samples;

3- Repetition of the previous routines 999 times, until the $I(1000)$ index was calculated.

The Moran statistical significance $I$ was weighted from the following hypotheses:

- H0: $I=0$ (there is no spatial correction between the studied variables);

- H1: $I>0$ (there is a spatial correlation between the studied variables).

When all the values of the permutations are equally probable, it is assumed that there is no spatial correlation between the variables and the null hypothesis (H0) is accepted, since the variables are random, independent and homogeneously distributed. Statically, this observation is observed when the value -p is greater than the observed index value $I(0)$.

From this, the null hypothesis is rejected and the alternative hypothesis (H1), that the data set has spatial correlation and, consequently, these are distributed in aggregate form, when the value $-p$ is less than $I(0)$ (ANSELIN, 1995).

This stage's final product gave rise to a qualitative choropleth map, where the critical areas of the damage to roofs caused by hail could be identified in relation to social vulnerability. To supplement this analysis, the database of damage occurred was superimposed on a (quickbird), satellite image to identify and quantify the impact of hailstorms on the types of roofing materials.

\section{RESULTS AND DISCUSSION}

\section{Climatic and meteorological analysis of hailstorms}

Initially, it is necessary to describe the types of weather that preceded the day of the event (June 1, 2016). On May 24, after the passage of a frontal system, a polar migratory anticyclone began to act in the Rio Claro region, which resulted in a mass of air with polar characteristics (low temperatures and stable types of weather). This system prevailed for a few days with low temperatures and stable weather types, with a certain amount of atmospheric disturbance on the 28th, due to the passage of another cold front by the ocean.

On May 29, the already tropicalized air mass, which was affecting the region, began to suffer a strong influence of tropical instabilities from the interior of the continent, followed by strong air currents and heavy rains coming from the west and northwest, between the May 30 and 31, totaling $41 \mathrm{~mm}$ in 24 hours. It is noteworthy that these instabilities were intensified by a low-pressure system (front in occlusion) in the Atlantic Ocean, with the effects of a trough near the coast of São Paulo.

The data collected allowed the production of daily analysis graphs (Figure 1), showing the rhythmic variations of the climatic elements on an hourly basis for June 1, 2016. In this same graph, it is possible to visualize two synoptic charts and meteorological satellite images, in which the temperatures in the State of São Paulo stand out. 


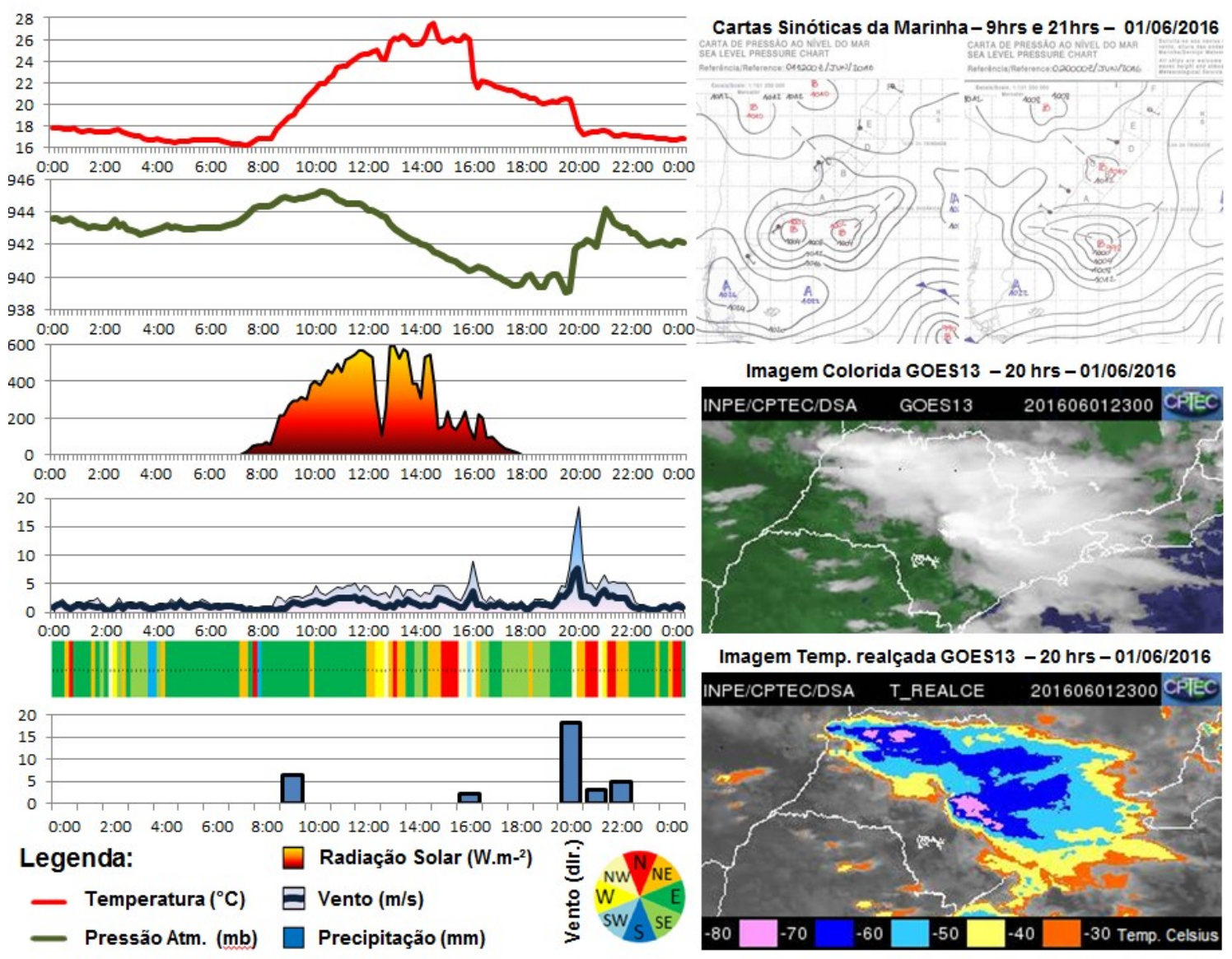

Figure 1: Graph of atmospheric variability for June 1, 2016

In Figure 1 it is possible to observe an occluded weather front (cyclonic vortex) on the Atlantic coast, which is influencing the interior of the State of São Paulo, through a line of instability. This system was followed by an expressive drop in the atmospheric pressure near the coast (the synoptic chart for 21 hours), during which the heavy northwestern currents entered through the trough, moving towards the municipality of Rio Claro.

This synoptic configuration resulted in the panorama portrayed in the meteorological satellite images, where it can be verified in greater detail at 20 hours. The enhanced image shows lower temperatures at the top of the cloud, just above Rio Claro; the color pink is indicative of storms and the further vertical development of the clouds.

On an hourly scale, it is possible to observe mild temperatures and some stability throughout the dawn, causing occasional rainfall in the morning due to the influence of humid weather. In the afternoon, there was a short burst of convective rainfall at 16 hours, resulting in a noticeable drop in temperature. However, the most disparate period of the day was between 19 and 22 hours, because there was a great variability in the climatic elements, due to the storm with hail precipitation.

During the hailstorm, winds above $66 \mathrm{~km} / \mathrm{h}$ were recorded. With the arrival of the convective system from the northwest, there was a sudden fall in the temperature and the atmospheric pressure, which rose afterward. At 22 hours, after the passage of the convective system, the weather became stable again.

Based on the IPMET weather radar images (located in the cities of Bauru and Presidente Prudente, São Paulo) on June 1, 2016, it is possible to monitor the development of the hailstorm that affected the Rio Claro region (Figure 2). The temporal sequence of the images produced during the day show the displacement of the convective systems (reddish and purple spots) over the territory of São Paulo, resulting in precipitations that were classified as very strong and / or extreme (Figure 2) and could be linked to the precipitation of hail. When analyzing Figure 2, rain of up to 100 millimeters is 
expected in the course of the atmospheric system.

In addition to the meteorological radar images, at $12: 30 \mathrm{pm}$, it is possible to verify the formation of a convective system over the municipality of Brasilândia, located east of the State of Mato Grosso do Sul, whose trajectory is directed towards the territory of São Paulo. In the image for 14:30 hours it is already possible to see a second convective cell forming near Fernandópolis (SP), whose trajectory continues to cause a strong storm towards the southeast. The convective systems unite to the south of the municipality of Catanduva (SP), at 17 hours, when there is an intense storm (reddish colorations in the center), and then they continue moving eastwards. In the image for 18:00 hours, the convective system loses intensity (absence of red color) and changes its trajectory, henceforth moving towards the southeast.


Figure 3: Sequence of meteorological radar images for June 1, 2016

From 18:45 hours onwards, it is already possible to notice a dark red color to the south of the convective system, evidencing that the storm has re-intensified before reaching the urban area of Rio Claro (SP) at approximately 19:15 hours, remaining over the city for more than fifteen minutes. After crossing the municipality of Rio Claro, in a southeasterly direction, causing damage, the system lost intensity when entering the municipality of Limeira (SP), dissipating gradually towards the east.

From the radar images it was possible to estimate the path (Figure 3) of the convective system responsible for the hailstorm. 


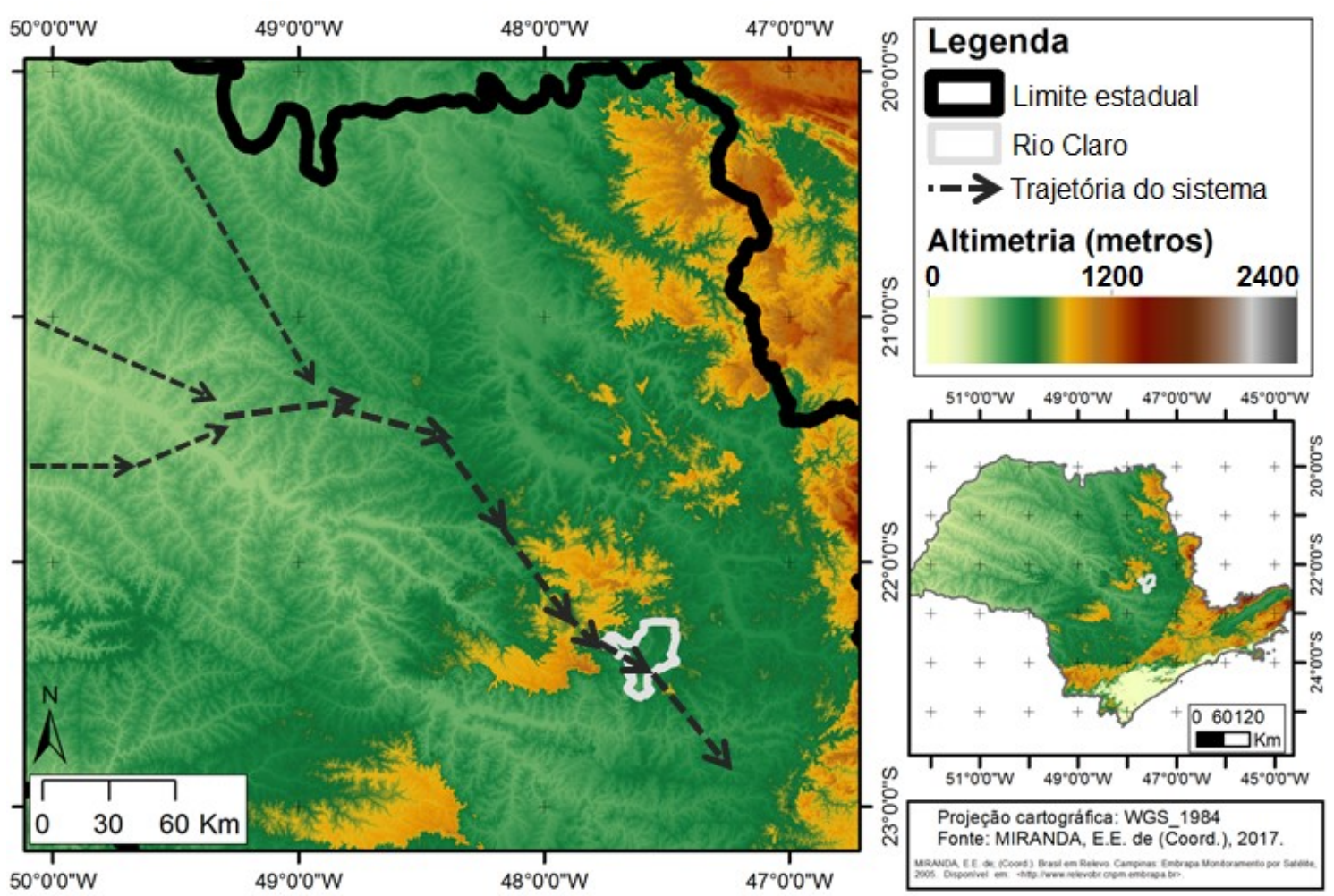

Figure 3: Trajectory of the convective system in the territory of São Paulo on June 1, 2016

From the joint analysis of Figures 3 and 4, it was possible to reinforce the hypothesis that the convective system gained intensity on passing through the region with the highest altimetry, located northwest of the municipality of Rio Claro (SP), under the control of the region of basaltic slopes. The geomorphological relief features steeper slopes and / or rocky outcrops as opposed to the softer slopes on the back of the cuesta (ROSS and MOROZ, 1997).

Despite having topographic gradients of around 600 meters, this physiographic configuration seems to have induced the atmospheric system to ascend and abruptly enter the back of the cuestas, contributing to the more intense precipitation in the municipalities of Itirapina (SP), Brotas (SP) and Ipeúna (SP), located in the west-northwest sector in relation to the municipality of Rio Claro (SP). In its trajectory, the different points in which the atmospheric system loses or gain intensity show, therefore, that the convection process is related to the relief, potentiating the instability, the formation of hail and the impact of the pluvial episode.

Associated with the factors above, the velocity of the convective system along the path was also relevant, since this parameter made it difficult to predict the phenomenon. As a result, the unpredictability of this extreme event increased the damage already mentioned.

\section{Spatial analysis of the damage caused by the hailstorm}

According to the Civil Defense's occurrences report, 93.7\% of the 126 residential and / or urban episodes of damage were caused by blown-off roofs, with the most affected districts being Boa Vista, Santa Maria, Parque Universitário and Novo Wenzel (Figure 4 ). 


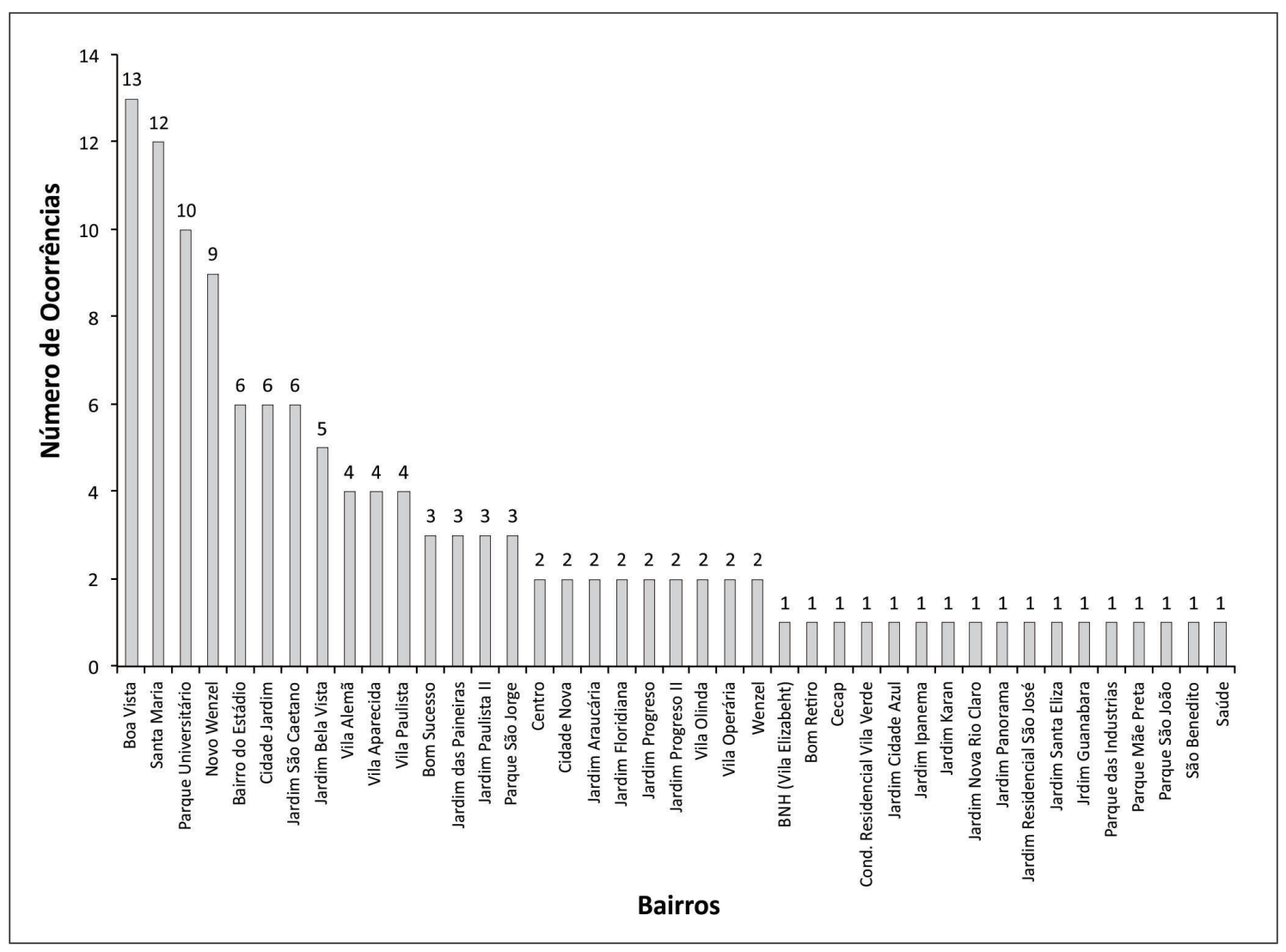

Figure 4: Number of damage episodes caused by hailstorms in the neighborhoods of Rio Claro (SP)

The spatial analysis of the damage caused by hailstorms can be illustrated by the variographic study (Figure 5). This geostatistical technique demonstrates the spatial variability of the damage, that is, it was possible to detect that the predominant direction of the events was from northwest to southeast (NO-SE). The spatial behavior of the variable studied allowed the adjustment of the experimental semivariogram to be performed with more precision. The conformation model found was the Gauseano with a range of 233 meters. This information allowed the measurement of the area of influence, verifying, therefore, that the structure of spatial autocorrelation of the damage caused by the hailstorm was 233 meters.

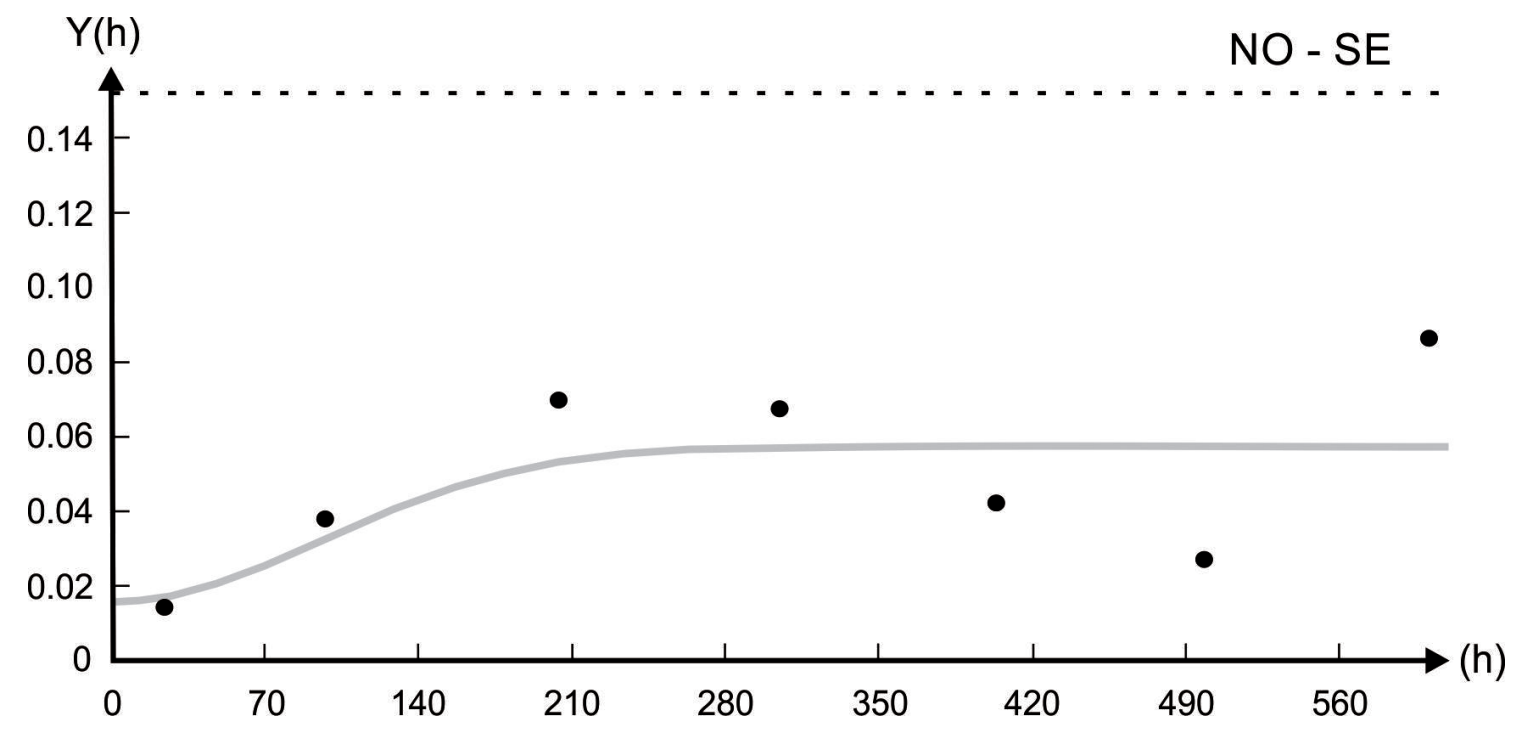

Figure 5: Adjusted Gaussian Semivariogram 
From this information, the radius of influence of the kernelestimator was stipulated and maps of densities of hail damage were created. In Figure 6, it is possible to identify that the areas with greater density of damage caused by the hailstorm are distributed in the northwest-southeast axis of the Rio-Clarense urban area.

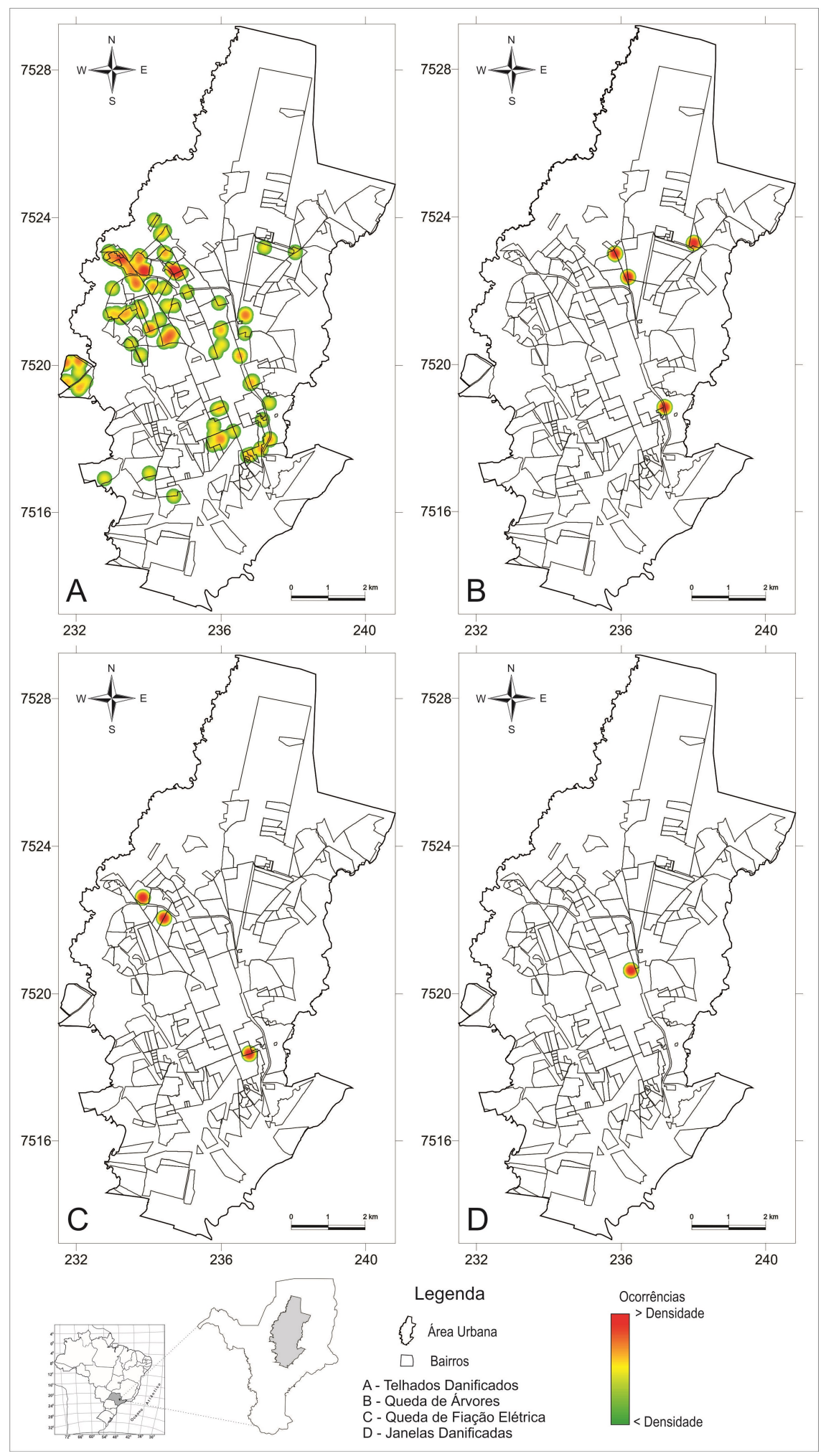

Figure 6: Cartograms of the damage caused by hailstorms in Rio Claro (SP). A - Blown-off roofs; B Fallen Trees; C - Fallen Electrical Cables and D - Broken Windows. 
Analyzing Figure 6, it is evident that the greatest concentration of records is in the districts located in the northwest sector of the city. Such spatialization corresponds to the entrance of the convective system coming from the northwest sector and losing intensity along its trajectory toward the southeast of Rio Claro.

In general, the spatialisation of the occurrences shows that roof damage (Figure 6A) was the most apparent type of damage caused by the storm in question, since the density of occurrences was higher in the northeast portion of the city.

\section{Spatial correlation of roof damage and social vulnerability}

The probable circumstance for the spatial and temporal pattern of the large number of impacts is anchored in the socioeconomic conditions of the families living in the urban area, since the construction standards may be more vulnerable to the atmospheric phenomenon in question (BEREZUK, 2009). With this in view, the spatial configuration of the occurrences of blown-off roofs and social vulnerability of the city of Rio Claro (SP) can be observed in figures 8 A and B, respectively.

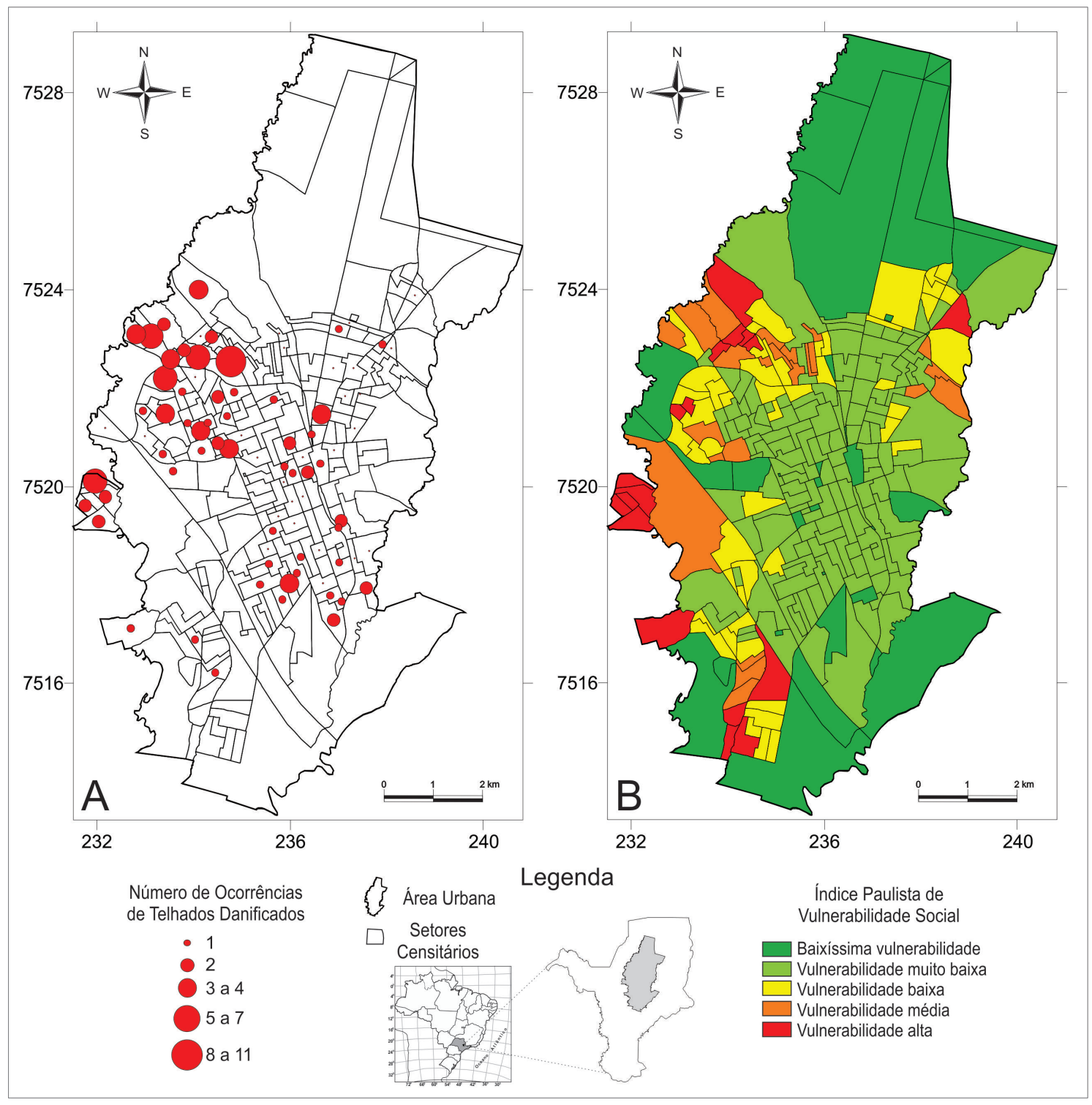

Figure 7: Number of Roofs Damaged (A) and Social Vulnerability Index (B) of the Census Sectors of the City of Rio Claro (SP).

In Figure 7B, the Paulista Social Vulnerability Index (IPVS) presents a distinct spatial pattern 
between the central region and the periphery, since in the areas distant from the center, except in the census tracts located to the east and southeast of the city, the social vulnerability of the population varies from medium to high.

These sites are characterized by the lowest income levels, in which residents survive on monthly incomings ranging from 1 to 3 minimum wages, coupled with poor sanitation and urban infrastructure. Among these areas on the outskirts of the city are the neighborhoods of Bom Sucesso, Novo Wenzel, Jardim Novo, Jardim Nova Rio Claro, Jardim Progresso, Jardim Santa Maria and Jardim Guanabara.

In the central and eastern areas of the city, it is noted that social vulnerability is low and / or very low. These areas are characterized by well-structured neighborhoods such as the Central Zone, Santana, Alto do Santana, Cidade Jardim, Vila Bela Vista, Vila Operária, Vila Vila, Vila Paulista and the other neighborhoods with high-end condominiums with family incomes varying between 7 and 10 minimum wages.

The spatial correlation performed through the application of the Moran Multivariate Local Index (Figure 8) shows the correlation between the extensiveness of the damage occurred and the trajectory of the hailstorm.
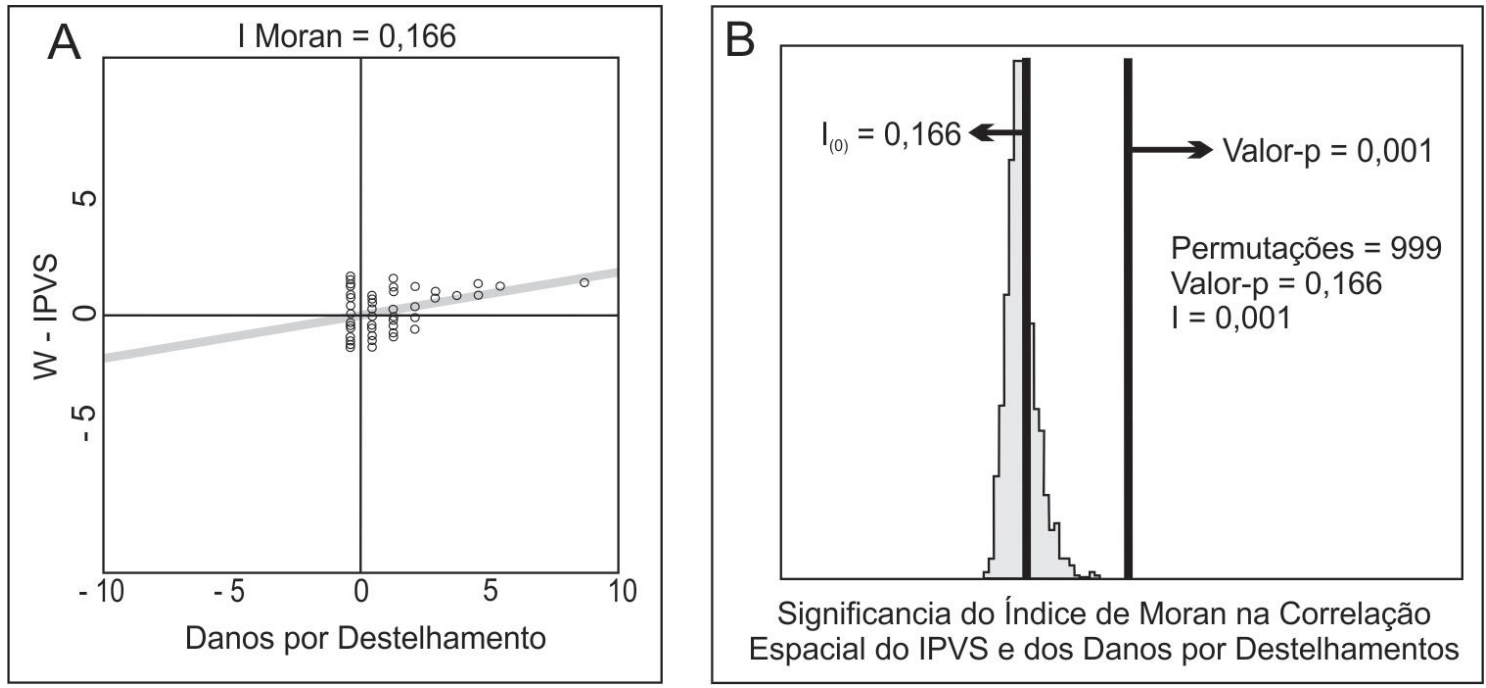

Figure 8: Spatial Correlation of the damage caused by blown-off roofs with the Paulista Social Vulnerability Index.

The bidimensional graph (Figure 8A) shows a direct positive correlation between the occurrences blown-off roofs and the Paulista Social Vulnerability Index (IPVS), where the Moran Multivariate Local Index presents a value of 0.166 . In the histogram (Figure $8 \mathrm{~B}$ ), the p-value is found to be 0.001 . From the results presented, the null hypothesis of absence of multivariate correlation among the studied variables is rejected, accepting the alternative hypothesis: that there is a spatial correlation between the damage to the roofs caused by hailstorms and the Paulista Index of Social Vulnerability (IPVS).

In Figure 9, one can observe the relation of the occurrences of blown-off roofs with the Paulista Index of Social Vulnerability (IPVS). In this illustration, the regions in red are the most vulnerable areas, located in the northeast sector and west of the urban area. 


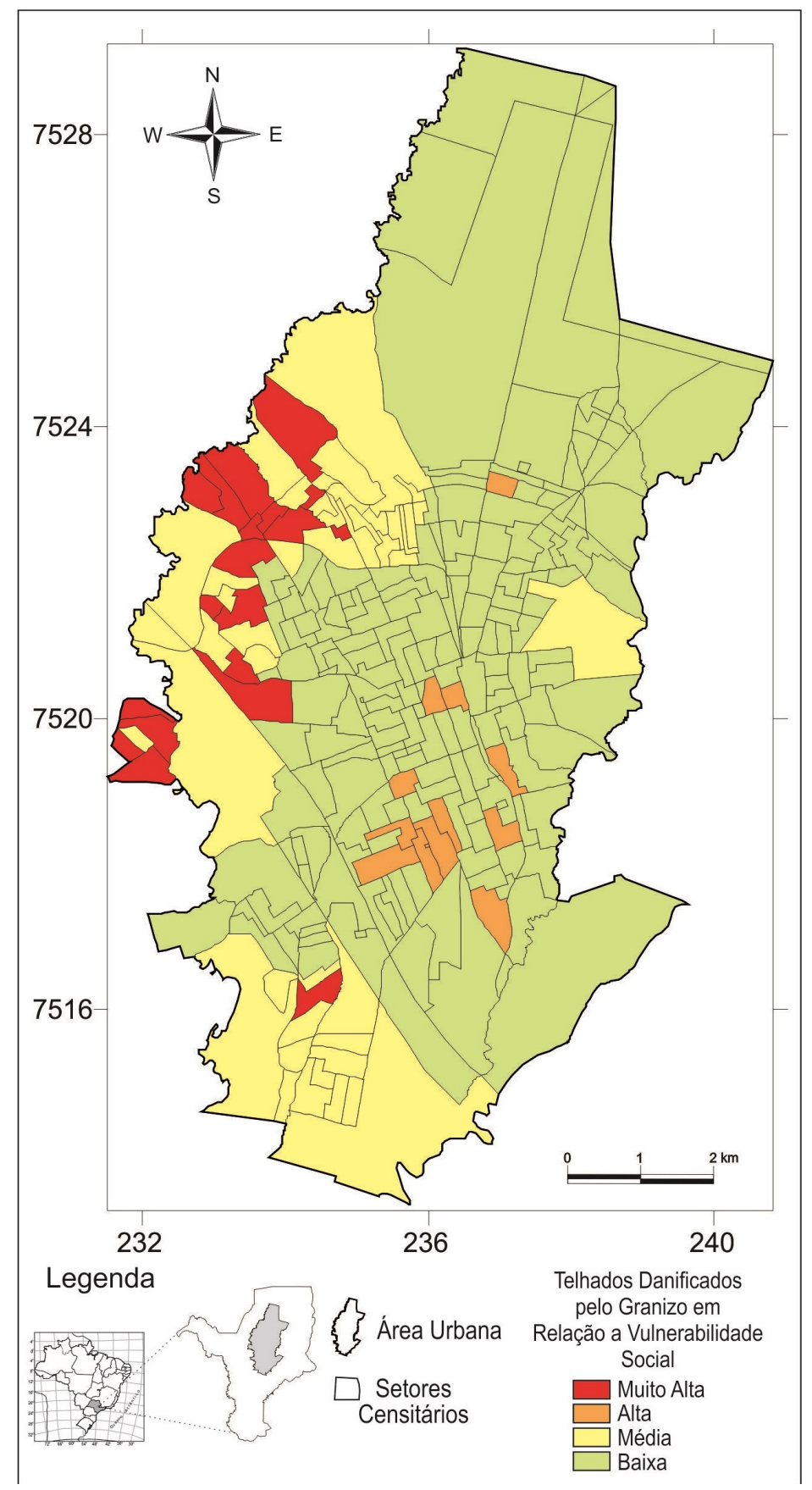

Figure 9: Relationship between the damage from blow-off roofs and the Paulista Index of Social Vulnerability in the Urban Area of Rio Claro (SP)

The results corroborate the study conducted by Berezuk (2009) in Maringá (PR), where the highest frequency of damage occurred in the outskirts of the city, where residences are usually covered by low-cost fiber cement roofing (Fig. 11) due to the low incomes of this population 


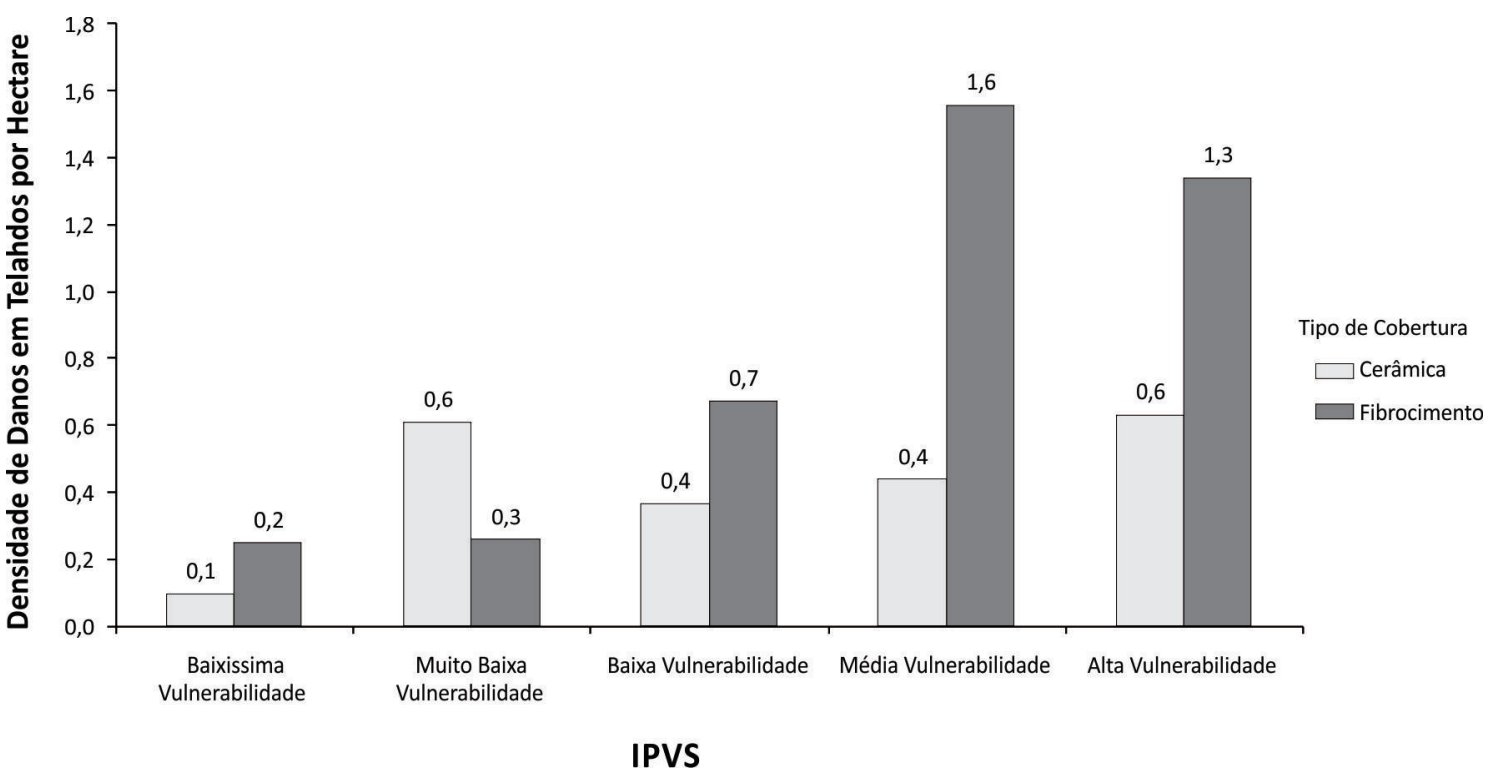

Figure 10: Density of Roof Damage by Hectare (ha) in relation to the Paulista Index of Social Vulnerability in the Urban Area of Rio Claro (SP)

Still in relation to the impacts of the episode highlighted in this study and according to data provided by the Civil Defense of Rio Claro, it is estimated that approximately $10 \%$ of the fleet of vehicles in the municipality of Rio Claro (BRAZIL, 2016) were hit by hail. In addition to the previously described impacts, another large impact caused by the hail was the high number of schools with severely affected roofing, totaling 23 units, three of which would have had to cease their activities if the rain had persisted, according to Director of the Civil Defense, as the tiles could not be restored under such conditions.

\section{CONCLUSION}

From the results obtained it was possible to identify the repercussions of a synoptic situation favorable to convective development, specifically, to the development of mesoscale convective systems, favoring the occurrence of hail precipitation. In the case examined, the consequences for the population living in the municipality of Rio Claro (SP) were extensive and serious. As this was an unprecedented situation in local weather records, it was an extreme event, for which the city was not prepared.

The spatial analysis, based on the occurrences registered by the Municipal Civil Defense, in the Paulista Index of Social Vulnerability (IPVS) and the typology of damaged roofs indicate the importance of social vulnerability in relation to the impacts that occurred. However, it should be noted that the magnitude of the damage suffered by the inhabitants of Rio Claro was high as a result of a synergism between the trajectory of the event, its duration and the location of the affected areas. Although the atmospheric system in question remained in the municipality for 15 minutes, it would not be possible to measure its impacts if the same system had reached Rio Claro's urban area along another trajectory and / or maintained its energy for a longer period of time.

Thus, it is evident that atmospheric events of this nature are difficult to predict and measure. It is, therefore, of the utmost importance that the agencies responsible for the prevention of environmental accidents should start to consider the future possibility of such events more seriously, so as to carry out the necessary mitigating measures related to severe natural disasters more efficiently.

\section{REFERENCES}

ANSELIN, L. Local indicators of spatial association - LISA. The Geographical Analysis. Ohio. v. 27, n. 2. p. $93-115.1995$. 
BARRY, R. G.; CHORLEY, R. J. Atmosfera, tempo e clima. Bookman: tradução Ronaldo Cataldo Costa, $9^{\text {a }}$ ed., Porto Alegre-RS, 2013.

BEREZUK, A. G. Eventos extremos: estudo da chuva de granizo de 21 de abril de 2008 na cidade de Maringá-PR. Revista Brasileira de Climatologia. v. 5, p. 153-164, 2009.

BIVAND, R. A review of spatial statistical techniques for location studies. Norwegian School of Economics and Business Administration. 1998. Disponível em: . Acesso em: 20 abr. 2017.

BLAIR, T. A.; FITE, R. Meteorologia. Escola Politécnica: tradução de Farid Cezar Chede, Rio de Janeiro, 1964.

BRASIL. Instituto Brasileiro de Geografia e Estatística. Cidades. 2016. Disponível em:. Acesso em: 10 nov. 2017

BRASIL. Instituto Brasileiro de Geografia e Estatística. 2010. Censo Demográfico 2010. Brasília, IBGE. Disponível em: . Acesso em: 15 jan. 20177.

CARVAlHO, M. S.; CÂMARA, G. Análise de eventos pontuais. In: Druck, S. et al. (Ed) Análise

Espacial de Dados Geográficos, Planaltina: EMABRAPA, 2004. 209p.

"CHUVA DE PEDRA" CAUSA MEDO E LEVA A DESTRUIÇÃO. Jornal Cidade (a). Rio Claro (SP), p.1, 02 jun. 2016.

COMO SE FORMA O GRANIZO. Zero hora. Porto Alegre (RS), p.9, 15/07/2016. CONSUMIDOR É PREJUDICADO E COMÉRCIO FATURA. Jornal Cidade (d). Rio Claro (SP), p.A6, 03 jun. 2016.

CONTI, J. B. A ocorrência do granizo no estado de São Paulo. Coleção Climatologia, $\quad$ n 9 , IGEOG/USP, 1981, 23p.

CRESSIE, N. Statistics for spatial data. New York: John Wiley \& Songs, 1993. 897p.

CUNHA, G. R. da; SCHEEREN, P. L.; SILVA, M. S. Granizo e cereais de inverno no Rio Grande do Sul. Passo Fundo: Embrapa Trigo, 2001.

CUNHA, G. R. da. Meteorologia: fatos \& mitos. Passo Fundo: Embrapa Trigo, 2003.

ESTRAGOS, MEDO E DESTRUIÇÃO EM TEMPORAL. Jornal Cidade (c). Rio Claro (SP), p.A7, 02 jun. 2016.

FRAGOSO, M. A utilização das imagens de radar meteorológico em climatologia. Finisterra, XXXI, n61, p.29-42, 1996.

FOTHERRINGHAM, A. S. et al. Quantitative geography. Londres: Sage. 2000. 270p.

KLANOVICZ, J. Chuvas de granizo e desastre nos pomares de maça catarinenses: produzindo uma agricultura de risco. Revista Esboços, Florianópolis, v. 20, n. 30, p. 67-89, dez. 2013.

LAR BETHEL E EMAÚS PEDEM AJUDA EM RC. Jornal Cidade (b), p.1, 03 jul. 2016.

MARTINS, J. A.; BRAND, V. S.; CAPUCIM, M. N.; FELIX, R. R.; MARTINS, L. D.; FREITAS, E. D.; GONÇALVES, F. L. T.; HALLAK, R.; DIAS, M. S. A. F.; CECIL, D. J. Climatology of destructive hailstorms in Brazil. Atmospheric Research, n. 184, p. 126-138, 2017.

MIRANDA, E. E. de; (Coord.). Brasil em Relevo. Campinas: Embrapa Monitoramento por Satélite, 2005. Disponível em: . Acesso em: 8 abr. 2017

MONTEIRO, C. A. F: A Frente Polar Atlântica e as Chuvas de Inverno na Fachada Sul-Oriental do Brasil (Contribuição metodológica à análise rítmica dos tipos de tempo no Brasil). São Paulo: USP/IG, 1969.p?

MONTEIRO, C. A. F. A Dinâmica Climática e as Chuvas no Estado de São Paulo: estudo geográfico sob a forma de atlas. São Paulo: USP/IG, 1973.

MONTEIRO, C. A. F. (Org.) A construção da Climatologia Geográfica no Brasil. Campinas, SP: Editora Alínea, 2015. 
ROSS, J. L. S.; MOROZ, I. C. Mapa geomorfológico do Estado de São Paulo. USP/IPT/FAPESP, 1997.

SÃO PAULO, FUNDAÇÃO SISTEMA ESTADUAL DE ANÁLISE DE DADOS - SEADE Índice Paulista de Vulnerabilidade Social (IPVS) - 2010. São Paulo: Governo do Estado de São Paulo, 2013. Disponível em: . Acesso em: 01 abr. 2017.

YAMAMOTO, J. K.; LAMDIM, P. M. B. Geoestatística: conceitos e aplicações. São Paulo: Oficina de Textos, 2013. 215p.

ZAVATTINI, J. A; BOIN, M. N. Climatologia Geográfica: teoria e prática de pesquisa. Campinas-SP: Editora Alínea, 2013. 145 p. 